\title{
Efficient processes with TPM in companies in the south central region of the state of Chihuahua
}

\section{Eficientar los procesos con el TPM en empresas de la región centro sur del estado de Chihuahua}

\author{
DELGADO-MARTÍNEZ, Martha Lilia, AGUIRRE-OROZCO, Mario Abelardo, MÁRQUEZ-
} MONÁRREZ, Olivia and GANDARILLA-NÚÑ̃EZ, Rafael

Tecnológico Nacional de México, Instituto Tecnológico de Delicias, Autores. Paseo Tecnológico Km. 3.5, C.P. 33000. Cd. Delicias, Chihuahua, México

ID $1^{\text {st }}$ Author: Martha Lilia, Delgado-Martínez / ORC ID: 0000-0002-5635-6853

ID $1^{\text {st }}$ Coauthor: Mario Abelardo, Aguirre-Orozco / ORC ID: 0000-0002-6899-5230

ID $2^{\text {nd }}$ Coauthor: Olivia, Márquez-Monárrez / ORC ID: 0000-0001-8549-5935

ID $3^{\text {rd }}$ Coauthor: Rafael, Gandarilla-Núñez / ORC ID: 0000-0003-0106-5001

DOI: $10.35429 / J F E .2019 .5 .3 .11 .16$

Received August 20, 2019; Accepted December 14, 2019

\begin{abstract}
In terms of maintenance talk of Mexico is of great importance because there is plenty of resources in order to be transformed, in the south central region of the state of Chihuahua, the municipality of Delicias, belongs to this area within its main activities are those related to the agriculture, livestock industries, the transformation of timber resources, as well as those relating to the derived from dairy products, within their major challenges is to eficientisar their production processes in order to prolong the life of the instruments, machinery and equipment of work of processing industries and processing of the different productive areas. To facilitate the tasks and quality service to consumers of these industries, with the application of techniques of Total Productive Maintenance. This through proper maintenance supported in a program adapted to the needs of production and wear of the systems used frequently, thus reducing the costs of same, corrections and contingency plans, ensuring the safety of workers and the proper functioning of the machinery. It is necessary to implement these measures, to not only keep the labor personnel safe, but also to provide a reduction of time and costs to firms, resulting in a better job available to customers, seen this by way of quality, delivery and service as well, using a system with improvements and quality from the inside to the outside, with the methodology of process engineering.
\end{abstract}

Process Engineering, Total, Productive Maintenance Efficiency

\begin{abstract}
Resumen
En términos de mantenimiento hablar de México es de gran importancia ya que existe infinidad de recursos para poder ser transformados, en la región centro sur del estado de Chihuahua, el municipio de Delicias, pertenece a esta zona que dentro de sus actividades principales se encuentran las relacionadas con el sector agrícola, ganadero, industrias de la transformación de los recursos maderables, así como también las concernientes a los derivados de los lácteos, dentro de sus principales retos es eficientar sus procesos de producción para de esta manera prolongar el periodo de vida de los instrumentos, maquinaria y equipo de trabajo de las industrias de transformación y procesamiento de las diferentes áreas productivas. Para con esto facilitar las tareas y servicio de calidad a los consumidores de dichas industrias, con la aplicación de técnicas de mantenimiento productivo total. Esto por medio de un correcto mantenimiento apoyado en un programa adecuado a las necesidades de la producción y desgaste de los sistemas utilizados frecuentemente, reduciendo así mismo, los costos por correcciones y planes contingentes, asegurando la seguridad de los trabajadores y el buen funcionamiento de la maquinaria. Siendo necesario implementar estas medidas, para no solamente mantener al personal laboral a salvo, sino también para proporcionar una reducción de tiempo y costos a las empresas, teniendo como consecuencia un mejor trabajo a disposición de los clientes, visto este a modo de calidad, entrega y servicio así, utilizando un sistema con mejoras y calidad desde el interior hacia el exterior, con la metodología de ingeniería de procesos.
\end{abstract}

Ingeniería de Procesos, Mantenimiento Productivo Total, Eficiencia

Citation: DELGADO-MARTÍNEZ, Martha Lilia, AGUIRRE-OROZCO, Mario Abelardo, MÁRQUEZ-MONÁRREZ, Olivia and GANDARILLA-NÚÑEZ, Rafael. Efficient processes with TPM in companies in the south central region of the state of Chihuahua. RINOE Journal-Financial Economy. 2019. 3-5: 11-16.

\footnotetext{
* Correspondence to Author (email: mldelgamar@hotmail.com)

$\dagger$ Researcher contributing first author.
} 


\section{Introduction}

In the central south region of the State of Chihuahua, there are 157 companies related to different productive sectors according to INEGI (2015), in their economic census, concerning the agricultural sector, livestock, as well as the industries of the transformation of timber resources and the dairy products, which within its main challenges is to streamline its production processes and thus prolong the life of the instruments, machinery and work equipment of the processing and processing industry of the different branches, for this facilitate quality tasks and service to consumers in these industries, with the application of total productive maintenance techniques. It is necessary to implement these measures to not only keep the workforce safe, but also to provide a reduction in time and costs to companies, resulting in better work available to customers, given this by way of quality, delivery and service. Thus, using a system with improvements and quality from the inside to the outside with the process engineering methodology.

Speaking of the evolution of maintenance, from the Industrial Revolution to the 40s, including the first part of the 50 s of the twentieth century, the concept of maintenance was to repair the equipment when it was damaged, from then until shortly before the 80's, maintenance began to be conceived as planning and scheduled repairs, in fact, it can be said that at the end of the 70s the first ideas of what today is the maintenance administration based on reliability were developed, concepts that had his first publications precisely in 1978 .

According to Newbrough (2005) Total Productive Maintenance is the translation of TPM (Total Productive Maintenance). It is the Japanese industrial maintenance system developed from the concept of "preventive maintenance" created in the United States industry. Total Productive Maintenance is a management system that avoids all kinds of losses during the entire life of the production system, maximizing its efficiency and involving all departments and all personnel from operators to senior management and guiding their actions based on Small group activities. The main innovation of T.P.M. is that operators are responsible for the basic maintenance of their own equipment.
They keep their machines in good working order and develop the ability to detect potential problems before they cause breakdowns. According to Dounce. V, (2006), the origin of the term Total Productive Maintenance (T.P.M.) has been discussed in various scenarios.

While some claim that it was initiated by American manufacturers more than forty years ago, others associate it with the plan that was used in the Nippodenso plant, a manufacturer of automotive electrical parts in Japan in the late 1960s Seiichi Nakajima, a senior official of the Japanese Plant Maintenance Institute (JIPM) receives the credit of having defined the concepts of TPM and to see for its implementation in hundreds of plants in Japan.

\section{Materials and methods}

The overall objectives of Total Productive Maintenance, is to reduce the six major losses, according to Niebel (2009), maximizes the effectiveness of the team through two types of approaches: quantitative, generating greater equipment availability and improving its productivity within a given period of operational time; qualitative, reducing the number of defective products stabilizing and improving quality. That is why this type of zero breakdown methodology will be developed in the south central region.

Using as an example companies in the agribusiness sector that are dedicated to pecans nut shelling. This research is carried out in order to develop standardized maintenance programs that help companies to take better control of the entire plant, as well as to apply the different types of maintenance to the machines, this depending on the degree of importance that have for the development of the process.

Building a facility maintenance program involves determining various types of tasks that require completion to ensure that the facility is operating efficiently and effectively. The TPM program consists in establishing a list of tasks outlining how long it takes to complete the task and who is responsible for ensuring its maintenance and completion. 
In this case, in the south central region there are seven companies dedicated to pecan nut processing, where a pilot program was developed that allowed its operators and administrators to have better control of the total productive maintenance of their facilities, which resulted in saving time and money, by reducing claims by a large percentage, as well as zero breakdowns that could occur in the future. In order to carry out the maintenance plan, first of all, you must know each of the teams that make up the process, developing technical sheets and thus be able to classify the resources as vital, important and trivial, in order to prolong the period of life of the instruments, machinery and work equipment of the food industry processing and processing industry, facilitating quality work and service to consumers in that industry.

Defining Total Productive Maintenance, as an administration system designed to facilitate the development of the industry. It relies on the proactive participation of all the staff that makes up the company, including suppliers. It is supported by the technical-administrative sciences that allow it to obtain a constant improvement in the productivity and quality of its products or services, emphasizing the prediction and prevention of zero defects, errors and failures of its resources. Starting from the needs of the clients, it is oriented to reorder the internal processes of the different areas of the company in order to make them more efficient.

With the TPM, as a privileged tool for the creation of Lean companies, which is a management methodology aimed at optimizing business assets through the total elimination of losses. By identifying these deteriorations in the production process and transforming them into opportunities for improvement, the TPM promoted cost reduction, identifying six major losses, the following being the following.

a) Losses due to breakdowns: breakdowns are the largest group of losses among the six mentioned. There are two types: function loss faults and function reduction faults. Failures of loss of function usually occur sporadically (suddenly) and are easy to detect since they are relatively dramatic: the equipment stops completely. On the other hand, reduced function failures allow the equipment to continue operating, but at a lower level of efficiency. b) Losses due to preparation and adjustment: these are losses due to interruptions that occur during the process, such as change of tools and begin when the manufacture of a product has been completed and ends when the standard quality is achieved.

c) Losses due to downtime and small downtime: unlike ordinary breakdowns, inactivity and small interruptions are the result of transient problems in the equipment.

d) Speed reduction losses: speed reduction losses occur when there is a difference between the speed provided in the design of the machine and its current operating speed. Speed reduction losses are generally ignored, although they constitute a major obstacle to the effectiveness of the equipment.

e) Quality Defects and Work Repetition: quality defects and repaired work are losses caused by machine malfunctions.

f) Start-up losses: the losses between start-up and stable production are; those that occur due to the reduced performance between machine start time and stable production.

\section{Problem Statement}

In some of these companies there is no adequate maintenance record for the equipment and machinery, which is essential because, if there was a control of the production, the process would not stop at any time and the costs for the company would decrease. There are several factors for which you do not have full control over this issue and this is one reason why the machines break down, among these you can include the human resource, as well as the pieces that make up each team and the care that is it gives among other aspects.

\section{Business situation (activities carried out)}

Cd. Delicias, Chihuahua is known for being an important nogalera region and for the nut processing business in the state, being a pioneer in the country in pecan nut production. The state procurement for the year 2017 was 51,316 tons, of which between 50 and $60 \%$ belongs to the edible part of the nut $(25,658$ to 30,790 tons $)$ and between 50 to $40 \%$ represents the nut shell $(25,658$ to 20,526 tons) (SIAP-SAGARPA, 2017). 
The pecan nut processors that are dedicated to the breaking and commercialization of the nut, their activities range from the selection to the sanitizing of the boxes with the walnut ready to ship them to different destinations, national and international. It is important to mention that each and every one of the different processes that are carried out in these industries are necessary for the product to have hygiene and quality.

\section{Current maintenance in companies}

The maintenance they perform in these companies is initially preventive, since they are responsible for greasing all the machines, motors and bearings, with a periodic routine sheet every month. In some equipment such as small breakers, the maintenance that is applied to them is at the beginning of each week, in which the bullets that they have internally are reviewed because they are sensitive after so many blows, because this is how these equipment operate. In large cracks the pieces that are most common that are damaged are the cups that are inside. On average, 97 to $157 \mathrm{AC}$ motors are changed per year, according to registered statistical data from these industries, this is because operators misplaced the bands or parts of the motor. Another of the pieces that are changed regularly are the bands and the bearings. In continuous dryers, they are not properly and timely preventive maintenance, so there are unforeseen events such as fires which should be avoided at all costs. In figure 1, a characteristic plant distribution of the nut processors is observed, which according to their process improperly locate the equipment, this being one of the main factors for this type of contingencies to occur. As can be seen in figure 1 , in the plant distribution there are many crosses of raw material, it is recommended to develop a reordering so that the process has a better fluidity of products and with this it is easier to transport a machine one cellar to another.

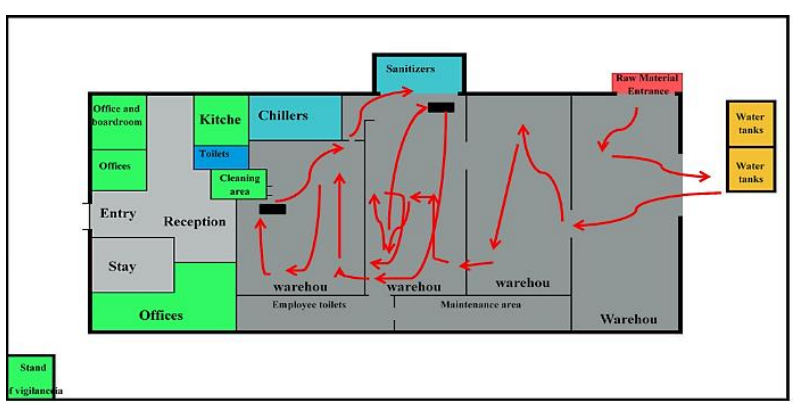

Figure 1 Plant distribution of a nut processing company Own source
In figure 2, the recommended plant distribution is appreciated so that there are not many raw material transport crossings, rearranging the equipment and therefore the production process so that it has a better fluidity and thus is more efficient.

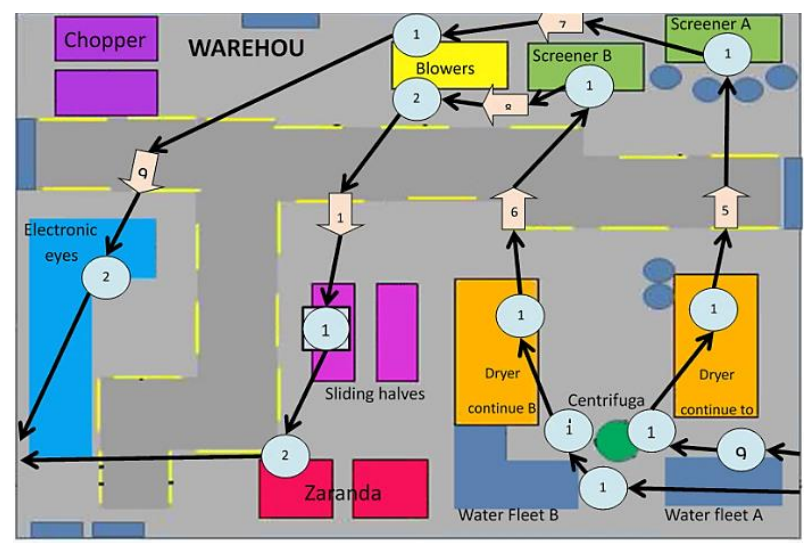

Figure 2 Recommended plant distribution to nut processors

Own source

\section{Engineering techniques and tools}

Within these companies, several positive and negative situations have been detected, so it is necessary to use different types of tools that support which parts are working well within the plant and other tools that help to verify in which aspects it is failing. Starting from simple tools such as the identification of machine types divided into codes, as well as the ICGM index that relates to the classification of resources divided into vital, important and trivial, to the most complex, which use different methods of collecting data. First, you must analyze the environment in which the company is developing, knowing its characteristics as its strengths and weaknesses, this is possible by means of a cause or Ishikawa diagram, helping to better understand each aspect of the plant and your work and thus you have the opportunity to generate a new diagram with the specific information of a given fault. Another tool that can be used for these purposes, is the flow process diagram, which will allow to know the sequence of production that is developed in the plants, to know if the order of the activities is in a properly structured way. Among the most important tools that should be used, are the technical data sheets, which will allow to know every aspect of the machinery with which one works in the companies, giving opportunity to know in what can fail and granting a wider knowledge of the same . 
As mentioned earlier, a very useful tool is the index of classification of the machinery in its different levels that they can acquire, as they are, vital, important and trivial. This in order to know which equipment should be given special attention, for example, to the machines that are at the critical points of the process. It is also important to know what are the aspects that should be taken care of within these companies, not only in terms of production, but also how it should be handled, as well as in what working conditions the machinery, facilities, for which a Very useful tool is the 5'S. Next, it is described in a cause-effect diagram in figure 3 , of the factors that affect the production systems according to research developed in these seven companies, their characteristics are very similar, being able to be established as a pilot plan to apply continuous improvement in these agribusinesses.

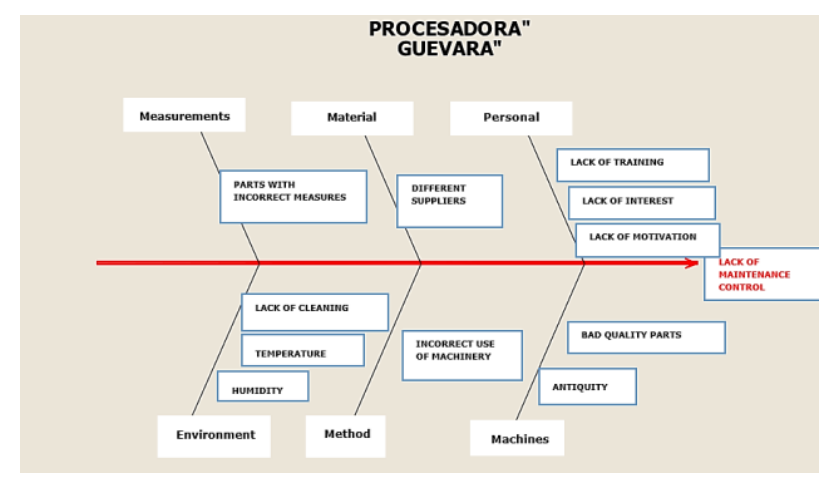

Figure 3 Most common causes of PMR in nut companies Own source

\section{Results and conclusions}

As a result to make efficient the manufacturing of pecan nut processing, in companies in the central south region of the state of Chihuahua, it is recommended to develop a standard total productive maintenance program, because their processes and plant distributions are very similar in these agribusinesses and according to the results obtained from the surveys applied in the field, related to the use of the different engineering techniques and tools that one of them applies, they served as the basis for this investigation, complementing with the causeeffect or Ishikawa diagrams, same which reflect the main causes of unexpected failures named 6M. (Labor, work method, machinery and equipment, materials, measurements and environment), are causes that really must be evaluated and taken care of to avoid that in these companies there are sudden interruptions in the production systems.
Taking into account all the above aspects, it is summarized that it is pertinent that each of the factors involved in the care of the safety and cleanliness of the equipment be taken care of in a timely manner, dedicating them the necessary time for its proper functioning.

The dryers are a critical point of the process of transformation of the pecanera nut since it is in this part where they are sterilized, this place must be taken care of even more than the conditions of hygiene to avoid that they can be contaminated again, another resource that must be monitor because they are vital resources are the electronic eyes that is the core part of the process where product sizes are selected for proper classification and can be shipped for marketing. In most of these agribusinesses, they do not have total productive maintenance control, in order to avoid the six major losses in the machines since there is an order, as well as a schedule for preventive maintenance. In addition to the fact that workers lack training to distinguish between different types of maintenance, it is therefore advisable to conduct training courses or workshops periodically to promote teaching in operators. During the tour in the companies it was observed that principles related to ergonomics need to be applied so that employees work comfortably, another point is cleaning to avoid accidents in the machines. As final recommendations, it is necessary to reconsider developing a plant redistribution, also performing periodic cleaning of electronic machines and equipment, as well as training personnel to encourage teamwork and using different engineering techniques and tools to manage total productive maintenance.

\section{References}

Dounce Villanueva, Enrique. (2006). Un enfoque Analítico del Mantenimiento Industrial. México: Grupo Patria. ISBN: \# 970-24-0914-4

Dounce Villanueva, Enrique. (2006). La Productividad en el Mantenimiento Industrial. México: Grupo Patria. ISBN: \# 978-968-261089-9

García Criollo Roberto. (2005). Estudio del trabajo, ingeniería de métodos y medición del trabajo. México: Mc Graw Hill. ISBN \# 9789701046579 
Janania Abraham, Camilo. (2008). Manual de tiempos y Movimientos. Ingeniería de Métodos. México: Limusa. ISBN-13: \# 978-968-18-70799

Kanawati George. (1996). Introducción al Estudio del Trabajo. Ginebra: Oficina Internacional del Trabajo. ISBN \#92-2-307-1081

Maynard H.B (1980). Manual de Ingeniería de la Producción Industrial. Barcelona: Reverte. ISBN \# 9788429126709.

Newbrough. E.T. (1997). Administración de Mantenimiento Industrial., México: Ed. Diana. ISBN \# 968-13-0666-X

Niebel-Freivalds. (2009). Ingeniería industrial, métodos, estándar y diseño del trabajo. México: Mc Graw Hill. ISBN \# 9789701069622

Nakajima, S. (ed.). (1989). Programa de desarrollo de TPM: implementando el mantenimiento productivo total. Cambridge, MA: Prensa de productividad. ISBN 9780915299379 